\title{
First report of maize yellow mosaic virus (MaYMV) on maize (Zea mays) in Tanzania
}

\author{
David Alan Read ${ }^{1}$. Jonathan Featherstone ${ }^{1}$. David Jasper Gilbert Rees ${ }^{1}$. Genevieve Dawn Thompson ${ }^{1}$. \\ Ronel Roberts ${ }^{2}$. Bradley Charles Flett ${ }^{3} \cdot$ Kingston Mashingaidze $^{3}$. Dave Kenneth Berger ${ }^{4}$ - Tanya Welgemoed ${ }^{4}$. \\ Gerhard Pietersen $^{5}$ (D) Susanna Elizabeth Schulze ${ }^{5} \cdot$ Barnabas Kiula $^{6} \cdot$ Alois Kullaya $^{7} \cdot$ Ernest Mbega $^{8}$
}

Received: 20 March 2018 / Accepted: 1 August 2018 / Published online: 15 August 2018

(C) Società Italiana di Patologia Vegetale (S.I.Pa.V.) 2018

Maize yellow mosaic virus (MaYMV) has been reported from China, Ecuador, Brazil and Burkino Faso on maize since 2016 and appears to be an emerging virus with a wide global distribution. Thirty-five maize samples with varying degrees of mosaic and stunting symptoms, were collected in May/June 2015 from the regions of Mara, Arusha, Manyara, Kilimanjaro, Morogoro and Pwani in Tanzania. Total RNA was extracted from leaf material, which was used to prepare RNAtag libraries according to Shishkin et al. (2015). Sequencing was carried out on an Illumina HiSeq2500 instrument. The reads from each dataset were taxonomically classified using the Kaiju software package (Menzel et al. 2016), with thirty datasets having reads showing homology to MaYMV, as well as either/both Maize chlorotic mottle virus and potyviruses. Trimmed

Gerhard Pietersen

gpietersen@sun.ac.za

1 Agricultural Research Council (ARC)- Biotechnology Platform, Pretoria, South Africa

2 ARC- Plant Health and Protection, Pretoria, South Africa

3 ARC- Grains Crops Research Institute, Potchefstroom, South Africa

4 Department of Plant and Soil Sciences, Forestry and Agricultural Biotechnology Institute (FABI), University of Pretoria (UP), Pretoria, South Africa

5 Department of Microbiology and Plant Pathology, FABI, UP, Pretoria 0002, South Africa

6 Ilonga Agricultural Research Institute (ARI-Ilonga), Kilosa, Morogoro, Tanzania

7 Mikocheni Agricultural Research Institute (MARI), Dar es Salaam, Tanzania

8 Nelson Mandela African Institute of Science and Technology (NM-AIST), Arusha, Tanzania datasets were assembled using CLC Genomics Workbench 9 de Novo assembly tool on default settings, with the exception of the following: "minimum contig length" (2000 bp), "length fraction" (0.9), "similarity fraction" (0.9). This yielded seven full/near full genomes with GenBank accession numbers MG664788 MG664794, sharing 97.9-99.9\% sequence homology. These sequences shared a 96.3-96.5\% (KU291105) and 97-97.3\% (KU291103) nucleotide identity with those from China. Seven positive samples were tested with RT-PCR, using the PCR primers MaYMV-F and MaYMV-R (Chen et al. 2016). Six samples produced the expected RT-PCR amplicon of $750 \mathrm{bp}$, with one potentially below the detection limit for RT-PCR. An RNA-seq negative sample did not produce the MaYMV amplicon but was positive for a maize control RT-PCR (actin), as expected. The identities of the amplicons were confirmed in four samples using Sanger sequencing. Next generation sequencing and PCR confirmed MaYMV positive samples in all sampled regions except Pwani. The broad geographical distribution of MaYMV in samples from this study suggests that the virus is well established in Tanzania.

\section{References}

Chen S, Jiang G, Wu J, Liu Y, Qian Y, Zhou X (2016) Characterization of a novel polerovirus infecting maize in China. Viruses 8(5):120. https://doi.org/10.3390/v8050120

Menzel P, Ng KL, Krogh A (2016) Fast and sensitive taxonomic classification for metagenomics with Kaiju. Nat Commun 7:11257

Shishkin AA, Giannoukos G, Kucukural A, Ciulla D, Busby M, Surka C, Chen J, Bhattacharyya RP, Rudy RF, Patel MM, Novod N, Hung DT, Gnirke A, Garber M, Guttman M, Livny J (2015) Simultaneous generation of many RNA-seq libraries in a single reaction. Nat Methods 12:323-325 